\title{
Emerging COVID-19 reinfection four months after primary SARS-CoV-2 infection
}

\author{
Helmut J. F. Salzer · Matthias Neuböck · Sven Heldt • Isabella Haug · Christian Paar · Bernd Lamprecht
}

Received: 4 November 2020 / Accepted: 7 January 2021 / Published online: 8 February 2021

(C) The Author(s) 2021, corrected publication 2021

To the editor In the last few months, several cases of ominous coronavirus disease 2019 (COVID-19) reinfections have been reported (Table 1). However, there is a scientific controversy whether reinfections can occur just a few months after the first infection and if so, what it means for the fight against the COVID-19 pandemic.

On October 27, 2020, a 95-year-old man was re-admitted from his retirement home to Kepler University Hospital in Linz, Austria with new onset dyspnea and fever. Four months before, he had been discharged after 2 weeks of hospitalization due to mild COVID-19 characterized by fever and leukopenia, but absence of viral pneumonia and hypoxia. For virological confirmation a severe acute respiratory syndrome coronavirus 2 (SARS-CoV-2) reverse transcription polymerase chain reaction (RT-PCR) was performed showing positive test results on June 27 with a cycle threshold (Ct) value of 32.2 and on July 2, 2020 with a Ct value of 37.7 (cobas 6800 SARSCoV-2 test, Roche, Molecular Systems, Branchburg, NJ, USA). Thereafter, the patient tested negative for SARS-CoV-2 on several occasions including at discharge from hospitalization on July 6 and 7 as well as on September 25 and on October 1, 2020. The patient had a medical history of dementia, arterial hypertension and total thyroidectomy.

H. J. F. Salzer, MD, MPH (凶) $\cdot$ M. Neuböck · S. Heldt ·

I. Haug · B. Lamprecht

Department of Pulmonology, Kepler University Hospital,

Linz, Austria

helmut.salzer@kepleruniklinikum.at

C. Paar

Institute of Laboratory Medicine, Kepler University Hospital, Linz, Austria
Referring to local COVID-19 infection precaution regulation the patient was directly isolated in the emergency room and he was again tested for SARSCoV-2 on October 27, 2020. Meanwhile vital parameters were taken showing a reduced oxygen saturation of $89 \%$ on room air and an elevated body temperature of $38.4^{\circ} \mathrm{C}$. Auscultation of the lung revealed no pathological abnormalities, while laboratory test results showed mild leukopenia with $3.18 \mathrm{G} / \mathrm{L}$ (reference value $3.9-8.8 \mathrm{G} / \mathrm{L}$ ) with a decreased lymphocyte count of $0.64 \mathrm{G} / \mathrm{L}$ (reference value $1.00-4.00 \mathrm{G} / \mathrm{L}$ ) and a thrombocytopenia with $126 \mathrm{G} / \mathrm{L}$ (reference value 151-400G/L), respectively. Other laboratory values and urine test results were unremarkable.

Two hours later the patient was again tested positive for SARS-CoV-2 with a Ct value of 12.8 in the RT-PCR (Cepheid Xpert Xpress SARS-CoV-2 point-ofcare test, Sunnyvale, CA, USA). Another oropharyngeal swab was taken confirming the positive SARSCoV-2 RT-PCR test result with a Ct value of 14.5 using a different platform (cobas 6800 SARS-CoV-2 test, Roche, Molecular Systems, Branchburg, NJ, USA).

Despite primary SARS-CoV-2 infection the patient this time required additional oxygen and had viral pneumonia on chest X-ray. Furthermore, the patient received low molecular weight heparin with enoxaparin 4000 I.E. subcutaneously once daily for prophylaxis of venous thromboembolism and paracetamol $1000 \mathrm{mg}$ intravenously as antipyretic treatment. Antiviral treatment was not administered due to drug shortage of remdesivir in Upper Austria at this time. We did not give dexamethasone at admission because the patient was not critically ill, he had no laboratory findings of hyperinflammation and was in the early phase of viral infection. Over the next few days the patients' respiratory condition deteriorated continuously consistent with a severe course of COVID-19. Finally, the patient deceased 6 days after admission. 
Table 1 Clinical characteristics of symptomatic COVID-19 reinfections having a negative SARS-CoV-2 PCR between the first and the second infection and/or a phylogenetic analysis

\begin{tabular}{|c|c|c|c|c|c|c|c|c|c|}
\hline Country & Sex & $\begin{array}{l}\text { Age } \\
\text { (years) }\end{array}$ & Comorbidities & $\begin{array}{l}\text { 1st in- } \\
\text { fection }\end{array}$ & 2nd infection & $\begin{array}{l}\text { Interval between } \\
\text { 1st and 2nd } \\
\text { infection }\end{array}$ & $\begin{array}{l}\text { Negative SARS-CoV-2 } \\
\text { PCR between 1st and } \\
\text { 2nd infection }\end{array}$ & $\begin{array}{l}\text { Phylogenetic } \\
\text { analysis }\end{array}$ & Reference \\
\hline Israel & Female & 20 & None & Mild $^{\mathrm{a}}$ & $\begin{array}{l}\text { Asympto- } \\
\text { matic }\end{array}$ & 112 days & Yes & No & [5] \\
\hline Ecuador & Male & 46 & N/A & Mild & Mild & 63 days & N/A & Yes & [6] \\
\hline USA & Male & 82 & $\begin{array}{l}\text { Parkinson's disease, di- } \\
\text { abetes, chronic kidney } \\
\text { disease, hypertension }\end{array}$ & Severe $^{b}$ & Severe & 55 days & Yes & No & [7] \\
\hline Hong-Kong & Male & 33 & N/A & Mild & $\begin{array}{l}\text { Asympto- } \\
\text { matic }\end{array}$ & 142 days & Yes & Yes & [4] \\
\hline USA & Male & 25 & None & Mild & Mild & 48 days & Yes & Yes & [8] \\
\hline Belgium & Female & 51 & $\begin{array}{l}\text { Asthma (inhaled cortico- } \\
\text { steroids) }\end{array}$ & Mild & Mild & 93 days & No & Yes & [9] \\
\hline $\begin{array}{l}\text { The Nether- } \\
\text { lands }\end{array}$ & Female & 89 & $\begin{array}{l}\text { Waldenström's macroglo- } \\
\text { bulinemia }\end{array}$ & Mild & Moderate ${ }^{c}$ & 59 days & No & Yes & [10] \\
\hline USA & $\mathrm{N} / \mathrm{A}$ & N/A & $\begin{array}{l}\text { Emphysema, home oxygen, } \\
\text { hypertension }\end{array}$ & Moderate & Moderate & 144 days & Yes & Yes & [11] \\
\hline USA & Male & 42 & $\mathrm{~N} / \mathrm{A}$ & Mild & Mild & 51 days & No & Yes & [12] \\
\hline Brazil & $\begin{array}{l}1 \times \text { Female } \\
2 \times \text { Male }\end{array}$ & $\begin{array}{l}40,67 \\
47\end{array}$ & $\begin{array}{l}\text { Asthma, ancylosing } \\
\text { spondylitis, obesity, OSAS, } \\
\text { none }\end{array}$ & Mild & $\begin{array}{l}\text { Mild to } \\
\text { severe }\end{array}$ & $54,56,70$ days & Yes & No & [13] \\
\hline Austria & Male & 95 & $\begin{array}{l}\text { Dementia, hypertension, } \\
\text { total thyroidectomy }\end{array}$ & Mild & Severe & 124 days & Yes & No & - \\
\hline \multicolumn{10}{|c|}{$\begin{array}{l}\text { COVID-19 coronavirus disease 2019, SARS-COV-2 severe acute respiratory syndrome coro } \\
\text { structive sleep apnea syndrome } \\
\text { a'Symptomatic with absence of hypoxia } \\
\text { bCritical ill requiring non-invasive or invasive ventilation and/or death related to COVID-19 } \\
\text { 'Symptomatic requiring additional oxygen }\end{array}$} \\
\hline
\end{tabular}

Taken this together a COVID-19 reinfection seems to be plausible in our patient 124 days after primary SARS-CoV-2 infection, although a recently published clinical meta-analysis including 15 single or cumulative case reports did not find any clinical reinfection after a 70-day period following first infection [1]. These findings are supported by animal studies demonstrating protection against reinfection in rhesus macaques after primary exposure to SARS-CoV-2 $[2,3]$.

Nevertheless, the first and the second COVID-19 episode in our patient were characterized by clinical symptoms, typical laboratory findings including leukopenia and thrombocytopenia as well as repeated virological confirmation of SARS-CoV-2 infection, while he had no symptoms and he tested negative on several occasions in between. To KK-W et al. also reported a reinfection in a 33-year-old man 142 days after first infection. Whole genome sequencing confirmed that both COVID-19 episodes were caused by phylogenetically diverse SARS-CoV-2 strains, which supports our clinical observation of reinfection instead of persistent viral shedding [4]. Questions remain, for example, why this patient acquired a COVID-19 reinfection, while immunity against the virus is probable, at least in the short term, since SARS-CoV-2 reinfections are only reported occasionally despite the high COVID-19 prevalence worldwide. Explanations could be an infection with a different SARS-CoV-2 strain or an age-related impaired immune response. Unfortunately we were not able to perform a comparison of whole genome sequencing data due to missing sample material of the first episode of infection.

We want to draw attention to this emerging aspect in the COVID-19 pandemic since reinfections will certainly influence our future scientific, clinical, social and economic response to COVID-19 pandemic. It will raise considerable questions on innate and adaptive immune response, on herd immunity and on vaccine development.

Funding Open access funding provided by Kepler Universitätsklinikum Linz.

Conflict of interest H. Salzer, M. Neuböck, S. Heldt, I. Haug, C. Paar and B. Lamprecht declare that they have no competing interests.

Open Access This article is licensed under a Creative Commons Attribution 4.0 International License, which permits use, sharing, adaptation, distribution and reproduction in any medium or format, as long as you give appropriate credit to the original author(s) and the source, provide a link to the Creative Commons licence, and indicate if changes were made. The images or other third party material in this article are included in the article's Creative Commons licence, unless indicated otherwise in a credit line to the material. If material is not included in the article's Creative Commons licence and your intended use is not permitted by statutory regulation or exceeds the permitted use, you will need to obtain permis- 
sion directly from the copyright holder. To view a copy of this licence, visit http://creativecommons.org/licenses/by/4.0/.

\section{References}

1. Arafkas M, Khosrawipour T, Kocbach P, et al. Current meta-analysis does not support the possibility ofCOVID-19 reinfections. J Med Virol. 2020; https://doi.org/10.1002/ jmv.26496.

2. Deng W, Bao L, Liu J, et al. Primary exposure to SARS-CoV-2 protects against reinfection in rhesus macaques. Science. 2020;369(6505):818-23.

3. Chandrashekar A, Liu J, Martinot AJ, et al. SARS-CoV-2 infection protects against rechallenge in rhesus macaques. Science. 2020;369(6505):812-7.

4. To KK-W, Hung I-FN, Ip JD, et al. COVID-19 re-infection by a phylogenetically distinct SARS-coronavirus-2 strain confirmed by whole genome sequencing. Clin Infect Dis. 2020; https://doi.org/10.1093/cid/ciaa1275.

5. Nachmias V, Fusman R, Mann S, et al. The first case of documented Covid-19 reinfection in Israel. IDCases. 2020;22:e970.

6. Prado-Vivar B, Becerra-Wong M, Guadalupe JJ, et al. COVID-19 reinfection by a phylogenetically distinct SARSCoV-2 variant, first confirmed event in South America. SSRN. 2020; https://doi.org/10.2139/ssrn.3686174.
7. Duggan NM, Ludy SM, Shannon BC, et al. Is novel coronavirus 2019 reinfection possible? Interpreting dynamic SARS-CoV-2 test results through a case report. Am J Emerg Med. 2020; https://doi.org/10.1016/j.ajem.2020.06.079.

8. Tillett RL, Sevinsky JR, Hartley PD, et al. Genomic evidence for reinfection with SARS-CoV-2: a case study. Lancet Infect Dis. 2020.

9. Van Elslande J, Vermeersch P, Vandervoort K, et al. Symptomatic SARS-CoV-2 reinfection by a phylogenetically distinct strain. Clin Infect Dis. 2020.

10. Mulder M, van der Vegt DSJM, Oude Munnink BB, et al. Reinfection of SARS-CoV-2 in an immunocompromised patient: a case report. Clin Infect Dis. 2020.

11. Goldmann JD, Wang K, Roltgen K, et al. Reinfection with SARS-CoV-2 and failure of humoral immunity: a case report. medRxiv. 2020; https://doi.org/10.1101/2020.09. 22.20192443 .

12. Larson D, Brodniak SL, Voegtly LJ, et al. A Case of Early Reinfection with SARS-CoV-2. Clin Infect Dis. 2020.

13. Fernandes Valente Takeda C, Moura de Almeida M, Gonçalves de Aguiar Gomes R, et al. Case report: recurrent clinical symptoms ofCOVID-19 in healthcare professionals: a series of cases from Brazil. Am J Trop Med Hyg. 2020.

Publisher's Note Springer Nature remains neutral with regard to jurisdictional claims in published maps and institutional affiliations. 